Article

\title{
Development of Arabinoxylan-Reinforced Apple Pectin/Graphene Oxide/Nano-Hydroxyapatite Based Nanocomposite Scaffolds with Controlled Release of Drug for Bone Tissue Engineering: In-Vitro Evaluation of Biocompatibility and Cytotoxicity against MC3T3-E1
}

\author{
Wafa Shamsan Al-Arjan ${ }^{1}$, Muhammad Umar Aslam Khan ${ }^{2,3,4, *} \mathbb{0}$, Samina Nazir ${ }^{1}$, \\ Saiful Izwan Abd Razak ${ }^{3,5}$ and Mohammed Rafiq Abdul Kadir ${ }^{3}$ \\ 1 Department of Chemistry, College of Science, King Faisal University, P.O. Box 400, \\ Al-Ahsa 31982, Saudi Arabia; walarjan@kfu.edu.sa (W.S.A.-A.); ssamina@kfu.edu.sa (S.N.) \\ 2 Department of Polymer Engineering and Technology, University of the Punjab, Lahore 54590, Pakistan \\ 3 School of Biomedical Engineering and Health Sciences, Faculty of Engineering, Universiti Teknologi \\ Malaysia, Skudai 81300, Johor, Malaysia; saifulizwan@utm.my (S.I.A.R.); \\ rafiq@biomedical.utm.my (M.R.A.K.) \\ 4 School of Biomedical Engineering, Med-X Research Institute, Shanghai Jiao Tong University (SJTU), \\ 1954 Huashan Road, Shanghai 200030, China \\ 5 Centre of Advanced Composite Materials, Faculty of Engineering, Universiti Teknologi Malaysia, \\ Skudai 81300, Johor, Malaysia \\ * Correspondence: umar007khan@gmail.com or umar-786@sjtu.edu.cn
}

Received: 28 October 2020; Accepted: 18 November 2020; Published: 20 November 2020

\begin{abstract}
Fabrication of reinforced scaffolds to repair and regenerate defected bone is still a major challenge. Bone tissue engineering is an advanced medical strategy to restore or regenerate damaged bone. The excellent biocompatibility and osteogenesis behavior of porous scaffolds play a critical role in bone regeneration. In current studies, we synthesized polymeric nanocomposite material through free-radical polymerization to fabricate porous nanocomposite scaffolds by freeze drying. Functional group, surface morphology, porosity, pore size, and mechanical strength were examined through Fourier Transform Infrared Spectroscopy (FTIR), Single-Electron Microscopy (SEM), Brunauer-Emmet-Teller (BET), and Universal Testing Machine (UTM), respectively. These nanocomposites exhibit enhanced compressive strength (from 4.1 to $16.90 \mathrm{MPa}$ ), Young's modulus (from 13.27 to $29.65 \mathrm{MPa}$ ) with well appropriate porosity and pore size (from $63.72 \pm 1.9$ to $45.75 \pm 6.7 \mu \mathrm{m}$ ), and a foam-like morphology. The increasing amount of graphene oxide (GO) regulates the porosity and mechanical behavior of the nanocomposite scaffolds. The loading and sustained release of silver-sulfadiazine was observed to be $90.6 \%$ after $260 \mathrm{~min}$. The in-vitro analysis was performed using mouse pre-osteoblast (MC3T3-E1) cell lines. The developed nanocomposite scaffolds exhibited excellent biocompatibility. Based on the results, we propose these novel nanocomposites can serve as potential future biomaterials to repair defected bone with the load-bearing application, and in bone tissue engineering.
\end{abstract}

Keywords: arabinoxylan; apple pectin; biocompatibility; material science; nanotechnology; bone tissue engineering 


\section{Introduction}

Bone tissue engineering (BTE) is an advanced and possible alternative solution for current surgical bone grafting approaches using porous biomaterials. BTE aims to support, facilitate, and regenerate the damaged or fractured bones using porous scaffolds. It is an effective and quick solution to heal defects of bones, to eliminate the donor deficiency problem; source limitation, and problems with conventional tissue implants (allograft and autograph) [1,2]. The design and composition of the artificial bone is a major objective in bone regeneration, and choosing appropriate materials to fabricate nanocomposite scaffolds can meet this challenge. The nanocomposite scaffold should resemble the extracellular matrix (ECM) to facilitate the osteogenesis and must regenerate the host bone by restoring its functionality [3]. The porous scaffolds should facilitate the growth of osteogenic cells, which is an ideal property of the porous scaffolds. The porous scaffolds with appropriate structure, interconnected porosity, and greater surface area have a positive impact on bone regeneration that facilitates the tissue growth response [4]. The nanocomposite materials furnished with tailorable properties and desired characteristics have become potential biomaterials. The nanocomposite scaffolds can be fabricated with high porosity, interconnected surface area to mimic the properties of the natural bone, and high tensile strength for load-bearing applications.

Porous nanocomposite scaffolds are the possible and potential channel to address the defective bone issue through bone tissue engineering conventions. These enable the synthesis of structural properties to meet the requirements for pertinent bone regeneration and growth [5]. Freeze drying is a well-known method to fabricate porous scaffolds from polymeric nanocomposite with desired pore size and porosity. The freeze-drying technique is famous among researchers and scientists within the last decade to obtain porous biomaterials [6,7]. Nanocomposite scaffolds can be fabricated using different nanocomposite materials to get the desired shape, pore size, \% porosity, and other physicochemical characteristics. Several researchers have been focused on the synthesis of porous nanocomposite scaffolds using nanocomposite materials, using freeze drying methodology, to develop the multi-functional properties [8]. The self-bone regeneration mechanism can be activated by adding certain growth factors that encourage bone regeneration by securing neovascularization. These nanocomposite scaffolds provide a microenvironment due to their microstructure and polymeric matrix that resembles with extracellular matrix (ECM). The microenvironment and polymeric matrix support the bone mechanically by facilitating cell proliferation, cell differentiation, and migration. Hydroxyapatite (HAp) is a well-recognized biomaterial that is biocompatible, effectively bioavailable to the ECM, and can regulate the biomechanical properties of the host bone $[9,10]$.

Natural polymers have been frequently utilized as potential biomaterials in medical sciences due to their biocompatibility, biodegradability, and non-immunological response. The researchers are focused on natural polymers to develop biomaterials for addressing different medical issues. These natural polymers have popularity momentum due to their capability in fabricating effectively engaged porous nanocomposite scaffolds with controlled biocompatible and biodegradable behavior [11,12]. Arabinoxylan (AX) is a natural polymer. $\mathrm{AX}$ and its derivatives have potential applications in tissue engineering, and other medical applications, due to its biocompatible, antioxidant, and anti-inflammatory properties. The backbone of AX is similar to that of glycosaminoglycans and it is a major ECM component of the cartilage bone. Henceforth, AX-based scaffolds can facilitate and support defective bone regeneration $[8,13]$. Pectin is a well-known natural polymer and is obtained from apple pulp, beetroot, and citrus fruits, etc. Pectin is an anionic polysaccharide and it possesses different chemical characteristics with several biomedical applications [14]. It is hydrophilic by nature and retains substantial water that facilitates cell proliferation and migration. Pectin has a similar structure to ECM and can induce different cellular functionalities to enhance the growth of cells [14]. The polymeric matrix of pectin has various carboxylate groups that help the crystallization of calcium and phosphate ions to regenerate calcified bone tissue [15]. The natural polymers based composite material are lacking in mechanical strength, which can be addressed by adding different fillers. Graphene oxide (GO) is a well-known filler that has been used in biomedical applications [16]. 
It has also gained recognition among researchers because of its high surface area, extremely versatile structure, flow, and movement of electrons with extraordinary mechanical strength [17,18]. In recent years, GO-based composite materials have been introduced in tissue engineering. GO-based composite materials have relatively low toxicity and high osteoinductive efficiency that facilitates rapid cell growth with loading application in bone tissue engineering $[19,20]$. Different composite materials have been introduced to regenerate and repair defective bone in tissue engineering.

In this research, polymeric nanocomposite materials have been synthesized using $A X, A P$, and nHAp with a variable amount of GO through free-radical polymerization. These polymeric nanocomposites were used to fabricate nanocomposite scaffolds (NCSs) using freeze drying methods. According to the best of our knowledge, these compositions have never been reported before in tissue engineering. The structural analysis and morphology have been analyzed using FTIR, XRD, and SEM. The swelling, biodegradation, drug loading, and release analysis were performed. The in-vitro analysis of developed scaffold materials was performed using mouse pre-osteoblast (MC3T3-E1) cells to determine biocompatibility. The obtained results demonstrated that these nanocomposite scaffolds have excellent morphology, physicochemical behavior, and biocompatibility. These nanocomposite scaffolds may be promising future biomaterial to repair and regenerate fracture bone in bone tissue engineering.

\section{Method and Material}

\subsection{Material}

Arabinoxylan was extracted from the husk of Plantago ovata using a well-reported method by Saeed et al. [21]. Apple pectin (Cas No. 76828-100G), Acrylic acid $\left(\mathrm{C}_{3} \mathrm{H}_{4} \mathrm{O}_{2}\right)$ AAc), $N$,N'-methylene-bis-acrylamide $\left(N, N^{\prime}\right.$ MBA $\left.\left(\mathrm{C}_{7} \mathrm{H}_{10} \mathrm{~N}_{2} \mathrm{O}_{2}\right)\right)$, silver nitrate $\left(\mathrm{AgNO}_{3}\right)$ and potassium persulfate $\left(\mathrm{K}_{2} \mathrm{~S}_{2} \mathrm{O}_{8}\right)$, n-HAp (<100 nm particle size, $\left.\geq 95 \%\right)$, GO (763713-1G), Aqua ammonia, phosphate buffer saline (PBS) solution, and hydrochloric acid $(\mathrm{HCl})$ was received from Sigma-Aldrich, Malaysia. All chemicals are analytical grades and utilized without any purification.

Fetal bovine serum (FBS), L-glutamine penicillin/streptomycin, and Alpha-MEM ( $\alpha$-MEM) were supplied by ThermoFisher Scientific and Hyclone Laboratories Inc. The mouse pre-osteoblast (MC3T3-E1) cell-lines were purchased from the American Type Culture Collection (ATCC-USA).

\subsection{Synthesis Polymeric Nanocomposite}

The polymeric nanocomposites materials were synthesized through the free-radical polymerization process using arabinoxylan (AX) and apple pectin (AP) were grafted and doping of nHAp and GO into the polymeric matrix of AX-g-AP. Briefly, AX (1.0 g) and AP (1.0 g) was dispersed in deionized water separately and transferred into a three-necked round bottom flask. Then, $0.45 \mathrm{~mL}$ of AAc as monomer and $N, N^{\prime}$-MBA as crosslinker $(0.045 \%$ by weight of AAc) was added into the solution. Nano-hydroxyapatite ( $2 \mathrm{~g})$ as a primary component and GO $(0.1,0.2,0.3$, and $0.4 \mathrm{mg})$ as an auxiliary component was added slowly into three-neck round bottom flask. The reaction mixture was stirred for $2 \mathrm{~h}$ at $60{ }^{\circ} \mathrm{C}$. Later, $0.05 \mathrm{~g}$ of the initiator $\left(\mathrm{K}_{2} \mathrm{~S}_{2} \mathrm{O}_{8}\right)$ was added and stirred under an inert environment for another $3 \mathrm{~h}$ at $60{ }^{\circ} \mathrm{C}$. After that, the reaction was stopped by removing flow of nitrogen gas and reaction media was allowed to cool. The reaction media was vacuum filtered and the residue was washed several times with deionized water to remove unreacted chemicals. The residue was dried overnight at $50{ }^{\circ} \mathrm{C}$ in an oven and ground to get fine powder of polymeric nanocomposite materials. The nHAp and GO were doped into the polymeric matrix of AX-g-AP to produce polymeric nanocomposites as shown in the proposed chemical reaction (Figure 1 (Left-side)). 


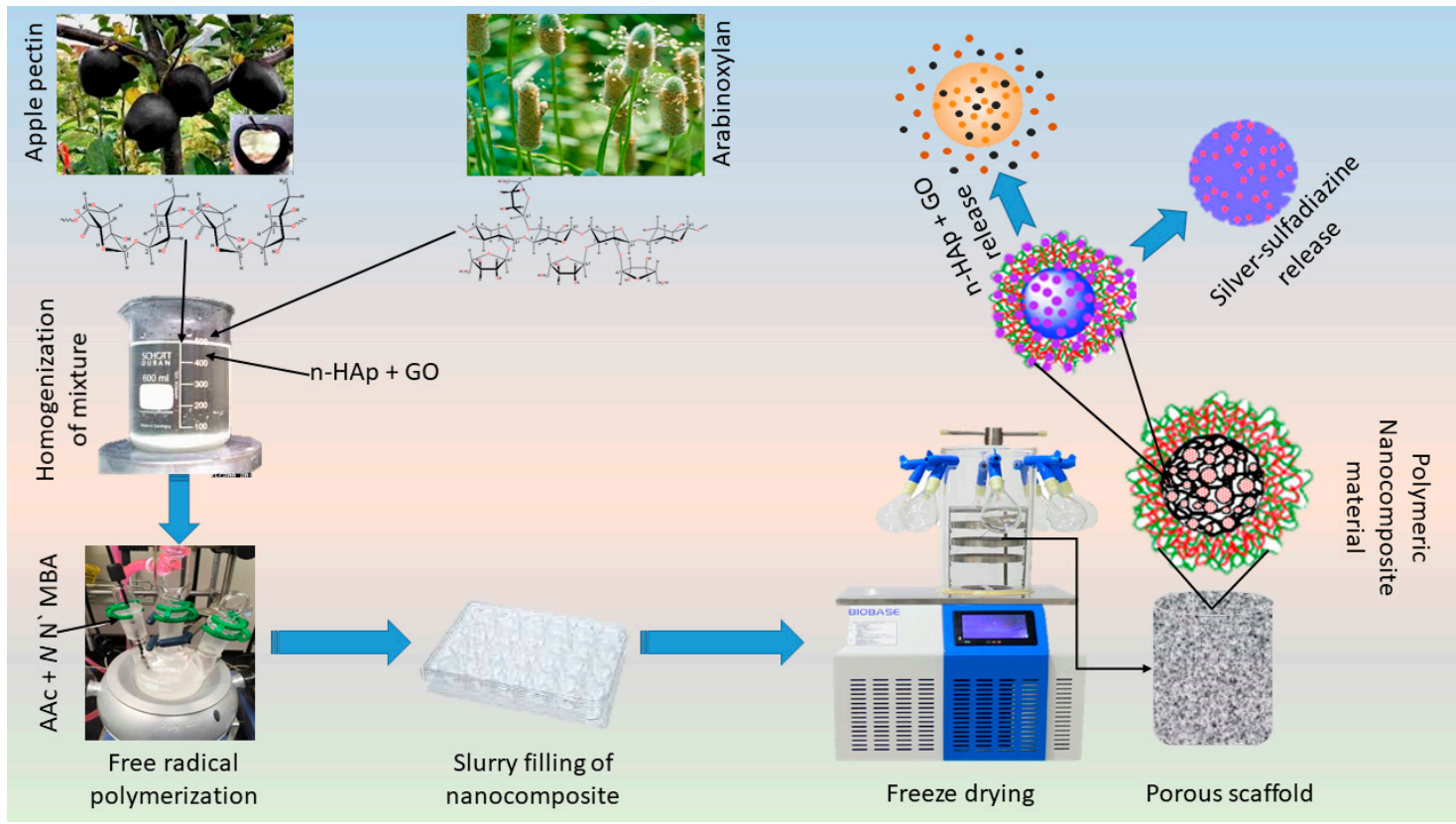

Figure 1. Experimental design. Polymeric nanocomposite scaffolds were synthesized by free radical polymerization to fabricate porous scaffolds via the freeze-drying method. Briefly, biopolymers (arabinoxylan, apple pectin), acrylic acid (monomer), n-HAp, and GO were stirred to have a homogenized mixture and crosslinked by using $N, N^{\prime}$-methylene-bis-acrylamide to form the hybrid nanocomposite. These hybrid nanocomposites were then freeze-dried to have porous scaffolds. Finally, the mouse pre-osteoblast (MC3T3-E1) cell line was used to evaluate in vitro behavior of these scaffolds.

\subsection{Fabrication of Nanocomposite Scaffolds}

The porous nanocomposite scaffolds were fabricated through the freeze-drying technique. Concisely, polymeric nanocomposite powder $(5 \mathrm{~g})$ was dispersed into deionized water and a homogenized slurry was made. The slurry was filled into a 24-well plate (Figure 2 (Right side)) and allow to freeze at $-80{ }^{\circ} \mathrm{C}$ for $24 \mathrm{~h}$. The frozen molds were freeze-dried to get porous nanocomposite scaffolds without any crack. Different codes NCS-1, NCS-2, NCS-3, and NCS-4 were assigned to nanocomposite scaffolds after different amounts of GO $(0.1,0.2,0.3$, and $0.4 \mathrm{mg})$. The proposed chemical reaction has been presented in the following schematic diagram (Figure 1).

\subsection{Loading of Silver-Sulfadiazine}

Silver-sulfadiazine ( $25 \mathrm{mg})$ was dissolved carefully into ethanol $(5 \mathrm{~mL})$ and added into deionized water $(45 \mathrm{~mL})$, and it was stirred to have a homogenized solution. Then, nanocomposite scaffold (NCS-4) was immersed into a beaker containing a silver-sulfadiazine solution for $1 \mathrm{~h}$ at room temperature. The beaker was kept in the oven $\left(50^{\circ} \mathrm{C}\right)$ under vacuum, until complete evaporation of the solvent, and to deposit the silver-sulfadiazine into the porous structure of the scaffold as shown in schematic diagram-I (Lower right-side). The drug release was determined into a PBS buffer solution ( $\mathrm{pH} 7.4$ at $37^{\circ} \mathrm{C}$ ). A $5 \mathrm{~mL}$ solution was taken after every $20 \mathrm{~min}$ and drug release was measured using a double beam UV-VIS spectrophotometer. The PBS buffer solution is taken as standard reference and the cumulative release of the drug was presented through the graph (Figure 7). 


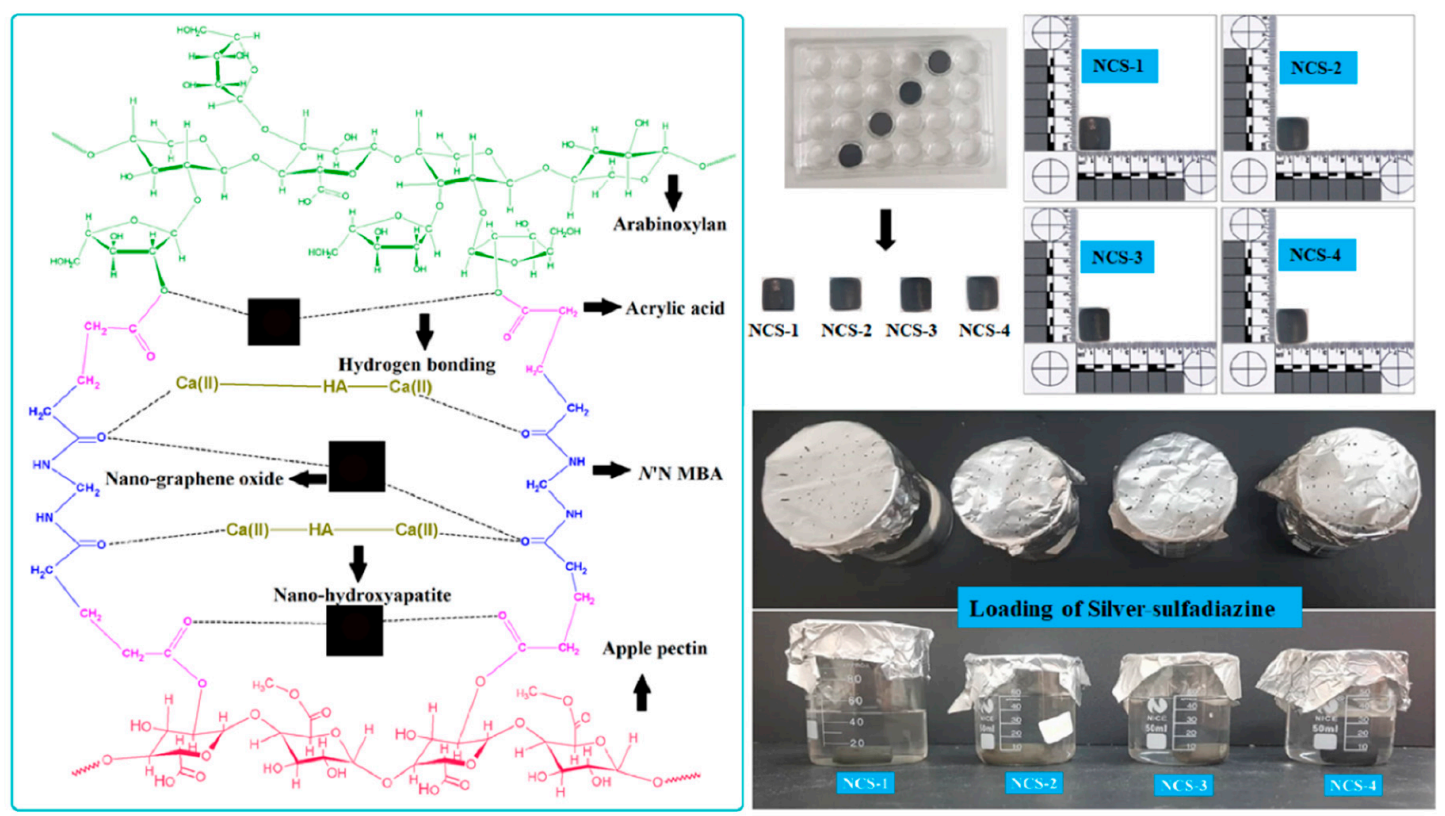

Figure 2. The scheme diagram presenting a proposed chemical reaction among the arabinoxylan (biopolymer), apple pectin (biopolymer), nano-hydroxyapatite (ceramic), nano-graphene, acrylic acid (monomer), and $N, N^{\prime}$-methylene-bis-acrylamide (crosslinker) for the synthesis of bioactive nanocomposite scaffolds through free radical polymerization method. These nanocomposites were freeze-dried to obtain porous scaffolds for bone tissue engineering and silver-sulfadiazine was loaded simple dipping technique.

\section{Characterizations}

\subsection{Fourier Transformation Infrared (FTIR)}

The functional group analysis of nanocomposite scaffolds was analyzed through Fourier transformation infrared (Shimadzu FTIR-8100A, Tokyo, Japan) with the range of $4000-400 \mathrm{~cm}^{-1}$ and 96 scans/s.

\subsection{Scanning Electron Microscopy (SEM)}

The surface morphological behavior of a well-dried and gold-sputtered nanocomposite scaffold was determined via scanning electron microscopy (JEOL-JSM 6480, Peabody, MA, USA). The porosity and pore sizes of nanocomposite scaffolds were analyzed using Brunauer-Emmett-Teller (Micromeritics Gemini II 2370, Norcross, GA, USA).

\subsection{Water Contact-Angle}

The homogenized slurry of the corresponding nanocomposite was placed into Petri dishes and allow drying in the oven at $45^{\circ} \mathrm{C}$ to measure the accurate contact angle. The wetting behavior of nanocomposite scaffolds was determined through contact angle measurement using contact angle meter (XCA-50) (VCA-Optima, AST Inc., Tacoma, WA, USA) and snaps were captured at different time intervals (1 and $10 \mathrm{~min}$ ) after dropping water drop $(4 \mu \mathrm{L})$ over the surface of nanocomposite film and tests were performed in triplicates.

\subsection{Mechanical Testing}

The mechanical testing strength of dried nanocomposite scaffolds was determined by a universal testing machine (ASTM D638) [22], (Testometrics, UK). The mechanical testing was performed at $10 \mathrm{~mm} / \mathrm{min}$ speed and the dimension of all scaffolds (height $1.7 \mathrm{~cm}$, diameter $1.5 \mathrm{~cm}$ ) was identical. The testing was performed in triplicate. 


\subsection{Biodegradation}

The nanocomposite scaffolds were cut into $1 \times 1 \mathrm{~cm}^{2}$ pieces, the weight was measured, and they were incubated in the PBS solution ( $\mathrm{pH} 7.4$ ) at $37^{\circ} \mathrm{C}$ for 35 days to observe the degradation rate. These nanocomposite scaffolds recovered from the PBS solution were rinsed with deionized water and dried in the oven for $1 \mathrm{~h}$ at $55^{\circ} \mathrm{C}$. The percentage of biodegradation was determined by following Equation (1).

$$
\text { Biodegradation }(\%)=\frac{W_{\mathrm{o}}-W_{\mathrm{t}}}{W_{\mathrm{o}}} \times 100,
$$

whereas: $W_{\mathrm{t}}=$ weight at a specific time, $W_{\mathrm{o}}=$ initial weight

\subsection{Swelling Analysis}

The swelling behavior of nanocomposite scaffolds was determined by PBS solution and deionized water at different temperatures $\left(35\right.$ and $37^{\circ} \mathrm{C}$ ). All scaffold samples were dried well and weighed before analysis. After a specific interval of time, the samples were taken out and surface water was removed carefully using tissue paper to record gained weight. The percentage swelling of the nanocomposite scaffolds was determined using Equation (2).

$$
\text { Swelling }(\%)=\frac{W_{\mathrm{f}}-W_{\mathrm{i}}}{W_{\mathrm{i}}} \times 100,
$$

whereas: $W_{\mathrm{f}}=$ final wet weight and $W_{\mathrm{i}}=$ initial dry weight.

\subsection{Release of Silver-Sulphadiazine from Nanocomposite Scaffold}

The silver release profile was studied through atomic absorption spectrophotometer (PerkinElmer, Inc., Waltham, MA, USA). The nanocomposite scaffolds were soaked into deionized water under standard in-vitro conditions $\left(37^{\circ} \mathrm{C}\right.$ and $\left.5 \% \mathrm{CO}_{2}\right)$. The cumulative release of silver was measured after every $20 \mathrm{~min}$ to analyze releasing.

\subsection{In-Vitro Biological Activities}

\subsubsection{Cell Viability and Optical Density}

Different concentrations of biomaterials $(0.50-2.00 \mathrm{mg} / \mathrm{mL})$ were prepared to study the cell viability. The MC3T3-E1 cell-lines were cultured by taking $0.1 \%$ gelatin (+ive control) and incubated under standard in-vitro conditions for different time intervals $(24,48$, and $72 \mathrm{~h}$ ). A well-reported method by Repetto et al. [23] was used to treat cells by incubating into the neutral red medium $(40 \mu \mathrm{g} / \mathrm{mL})$ for $2 \mathrm{~h}$ and washed PBS solution for another $2 \mathrm{~h}$ to remove the unnecessary neutral red stain. The dye-staining solution ( $50 \%$ distilled water, $49 \%$ absolute ethanol, and $1 \%$ glacial acetic acid) was used at $37{ }^{\circ} \mathrm{C}$ for $10 \mathrm{~min}$. The optical density of cultured MC3T3-E1 cell lines was observed at $570 \mathrm{~nm}$ using an absorbance microplate reader (ELx-800) (Bio-Tek, Winooski, VT, USA). The experiment was performed in triplicate and the percentage of cell viability was calculated by Equation (3).

$$
\text { Cell viability }(\%)=\frac{O D_{\mathrm{S}}}{O D_{\mathrm{C}}} \times 100,
$$

whereas: $O D_{\mathrm{S}}=$ sample concentration, $O D_{\mathrm{C}}=$ positive control

\subsubsection{Cell Morphology}

The pre-osteoblast cell-lines were maintained in $\alpha-M E M, 10 \%$ FBS, $1 \%(2 \mathrm{mM})$ L-glutamine, $1 \%$ penicillin/streptomycin. The density of pre-osteoblast cell-lines was assumed to be $5000 \mathrm{cells} / \mathrm{cm}^{2}$ in a $100 \mu \mathrm{m}$ cell culture plate ( 96 well plate). The well-plates were coated using a gelatin solution 
$(0.1 \%)$ as a coating agent. The well-plates were incubated with scaffolds (e.g., NCS-1, NCS-2, NCS-3, and NCS-4) at $37^{\circ} \mathrm{C}$ with $5 \% \mathrm{CO}_{2}$ and $90 \%$ humidity, which are standard in-vitro conditions.

\subsubsection{Cell Culture SEM Morphological Analysis}

The MC3T3-E1 cell was cultured over the nanocomposite scaffolds for 7 days and cell adherence was observed by SEM (JEOL-JSM-6480, Peabody, MA, USA). PBS solution was used to carefully wash the attached cells and at room temperature. The cell was fixed with absolute ethanol for $5 \mathrm{~min}$. These scaffolds samples were dried and gold-sputtered. The SEM analysis was performed at an accelerated voltage of $1 \mathrm{kV}$ under an operating pressure of $7 \times 10^{-2}$ bar with the deposition current of $20 / 2.0 \mathrm{~mA} / \mathrm{min}$.

\subsection{Statistical Analysis}

Experimental data was performed in triplicate and presented as mean standard errors (S.E). The statistical software (IBM, SPSS Statistics 21) was used to perform statistical analysis. The means and standard errors of means (mean \pm S.E) were analyzed for each analysis shown as $Y$-error bars in figures. $(p<0.05 ; n=3)$.

\section{Results and Discussions}

\subsection{FTIR}

The FTIR spectral analysis has been conducted to determine different functional groups and chemical interactions of nanocomposite materials as shown in Figure 3. The broadband at $3600-3200 \mathrm{~cm}^{-1}$ presents the stretching vibrations of the hydroxyl $(-\mathrm{OH})$ group; these vibrations' peaks present the hydrogen bonding. The increasing peak intensity causes more hydrogen bonding due to the increasing amount of GO [24,25]. The stretching vibration at $2930 \mathrm{~cm}^{-1}$ is due to a saturated aliphatic $\mathrm{C}-\mathrm{H}$ functional group. Furthermore, the broadband $3600-3200 \mathrm{~cm}^{-1}$ vibration may explain hydrogen bonding AX, AP, and GO [8]. The stretching vibration peaks at 1729, 1643, and $1430 \mathrm{~cm}^{-1}$ were attributed to $\mathrm{C}=\mathrm{O}, \mathrm{C}=\mathrm{C}$, and $\mathrm{C}-\mathrm{H}$, respectively, and these are basic functional groups of GO [26,27]. The vibration peak at $1056 \mathrm{~cm}^{-1}$ is a characteristic peak of saccharine that confirms the presence of polysaccharide (Arabinoxylan and apple pectin) $[8,28]$. The vibration bands at 1062 and $965 \mathrm{~cm}^{-1}$ attributes the triply degenerated $\mathrm{P}-\mathrm{O}$ stretching and $\mathrm{PO}_{4}{ }^{3-}$ bending of $\mathrm{HAp}$, respectively [8]. The asymmetric bending vibration of $\mathrm{P}-\mathrm{O}$ was attributed to $703-654 \mathrm{~cm}^{-1}$ that resembles HAp materials [26]. The successful synthesis of nanocomposite scaffolds was confirmed by these available spectral functional groups.

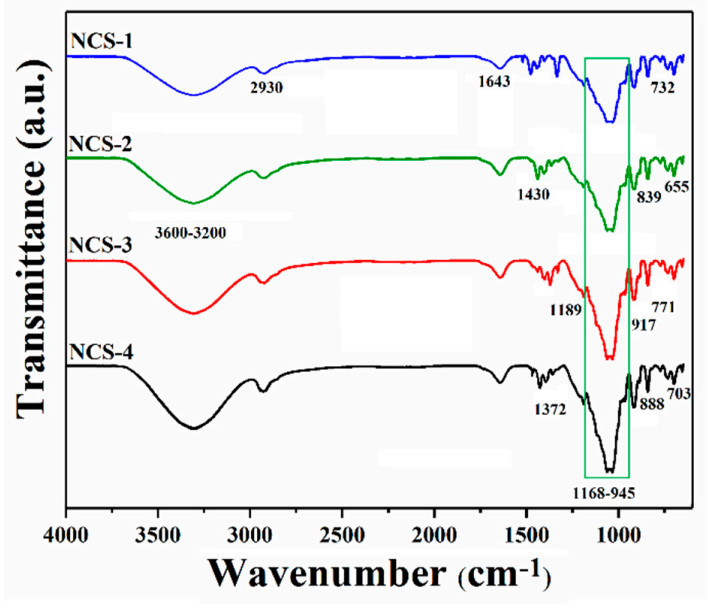

Figure 3. FTIR spectral profile of nanocomposite scaffolds to determine the different functional groups. 


\subsection{SEM Analysis}

Porosity allows the transportation of nutrients, the exchange of gases, cell infiltration, and migration into scaffolds to help growing new blood vessels. The surface morphologies of nanocomposite scaffolds have been shown at different magnifications (Figure 4). The increasing amount of the GO was found to be more interconnected with homogeneous pore distribution. The highly interconnected porous structure of nanocomposite scaffolds is necessary. The morphological properties are important to exchange gases, nutrient permeability wastes disposal, and retain maximum tissue fluid that facilitates the cell growth activities. These nanocomposite scaffolds can be suitable for cell proliferation and migration in bone tissue engineering applications [29,30]. The porous and interconnected morphology of nanocomposite scaffolds also confirms the successful scaffold fabrication and interaction of GO through H-bonding. Therefore, these nanocomposite scaffolds play a key role in the release of growth factor, drug delivery, cell migration for fracture bone regeneration [31]. Therefore, the optimized amount of GO can produce the desired porosity, as an increasing amount of GO regulates porosity and pore size. The addition of GO as filler imparts additional porosity. These nanocomposite scaffolds demonstrated the complete interconnected porosity with foam-like morphology (Figure 4). These characteristics are considered to be very significant for tissue and pore size 50-250 $\mu \mathrm{m}$ was found as best for cell adherence, growth, and proliferation [32,33]. No crack or major defect has been seen over the scaffolds and scaffolds displayed interconnected porosity and pore sizes that indicated strong control over the manufacturing process. The pore size and personage of porosity have been described in Table 1. The successful fabrication of porous nanocomposite scaffolds plays a crucial role in the fabrication of porous hybrid nanocomposite scaffolds with rough morphology [34].
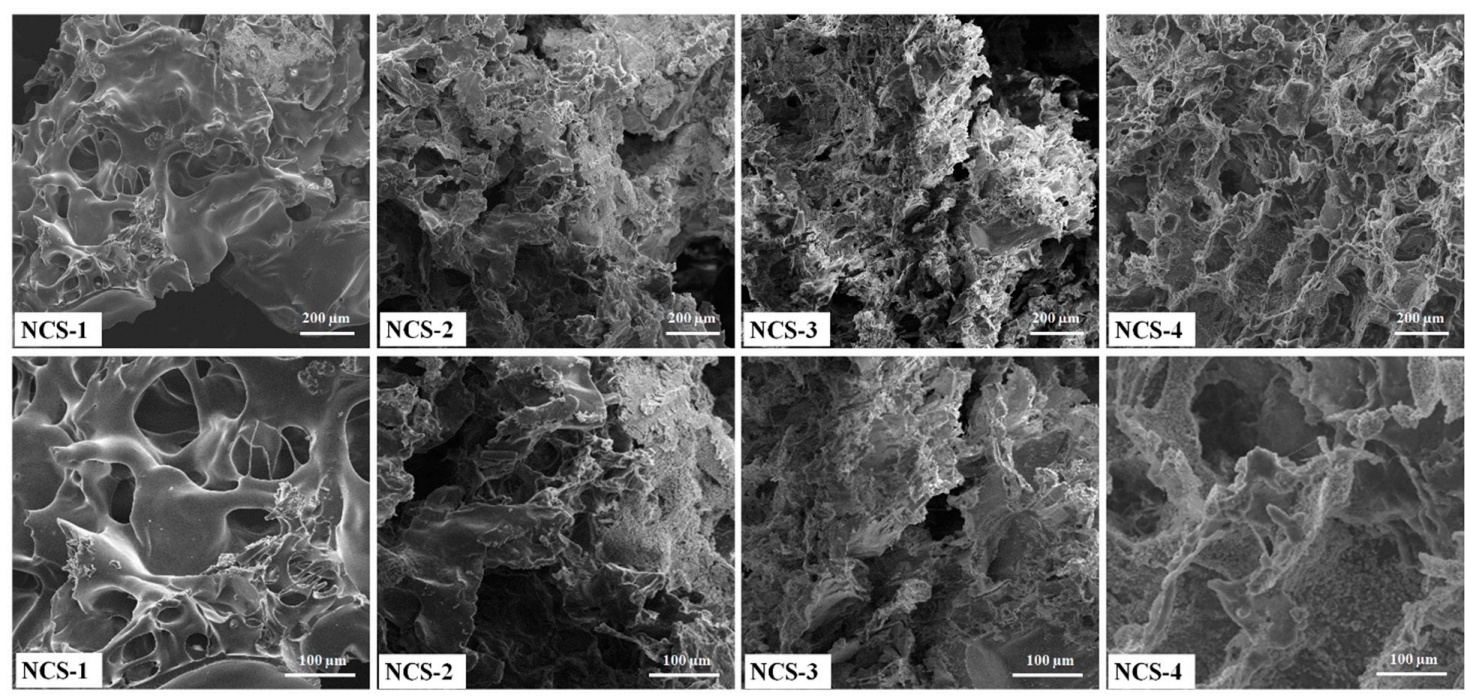

Figure 4. Presents the porous morphologies of the nanocomposite scaffolds at different magnifications.

Table 1. Present the mechanical properties of nanocomposite scaffolds.

\begin{tabular}{cccccc}
\hline Scaffold & $\begin{array}{c}\text { Strain } \\
(\mathbf{\%})\end{array}$ & $\begin{array}{c}\text { Stress } \\
\mathbf{( M P a )}\end{array}$ & $\begin{array}{c}\text { Young's } \\
\text { Modulus } \\
\mathbf{( M P a )}\end{array}$ & $\begin{array}{c}\text { Porosity } \\
\mathbf{( \% )}\end{array}$ & $\begin{array}{c}\text { Pore Area } \\
\left(\boldsymbol{\mu \mathbf { m } ^ { 2 } )}\right.\end{array}$ \\
\hline NCS-1 & 57.01 & 16.90 & 29.65 & $63.72 \pm 1.9$ & $0.64 \times 10^{3}$ \\
\hline NCS-2 & 49.80 & 12.9 & 25.90 & $56.23 \pm 3.4$ & $0.55 \times 10^{3}$ \\
\hline NCS-3 & 36.71 & 8.20 & 22.34 & $50.94 \pm 8.3$ & $0.46 \times 10^{3}$ \\
\hline NCS-4 & 30.92 & 4.1 & 13.27 & $45.75 \pm 6.7$ & $0.38 \times 10^{3}$ \\
\hline
\end{tabular}




\subsection{Water Contact-Angle}

The wetting behavior of nanocomposite scaffolds was determined using water contact angles after a different interval of time ( 1 and $5 \mathrm{~min}$ ) as shown in Figure 5. The sample NCS-4 was found to be more hydrophilic as compared to NCS-1, due to the increasing amount of GO, which shifts the wetting behavior from hydrophobicity toward hydrophilicity. The increasing time of water contact to the surface also increases the hydrophilicity. Hence, an increasing amount of GO in the nanocomposite scaffolds can lower the water contact angle and shift the wetting behavior from hydrophobic to hydrophilic. More hydrophilic character is an indication of hydrogen bonding that is fundamental for cell adhesion and cell proliferation [35,36]. It is also assumed that the increasing quantity of GO induced the nanocomposite scaffold increases the hydrogen bonding and the high biological activity was observed NCS-4.

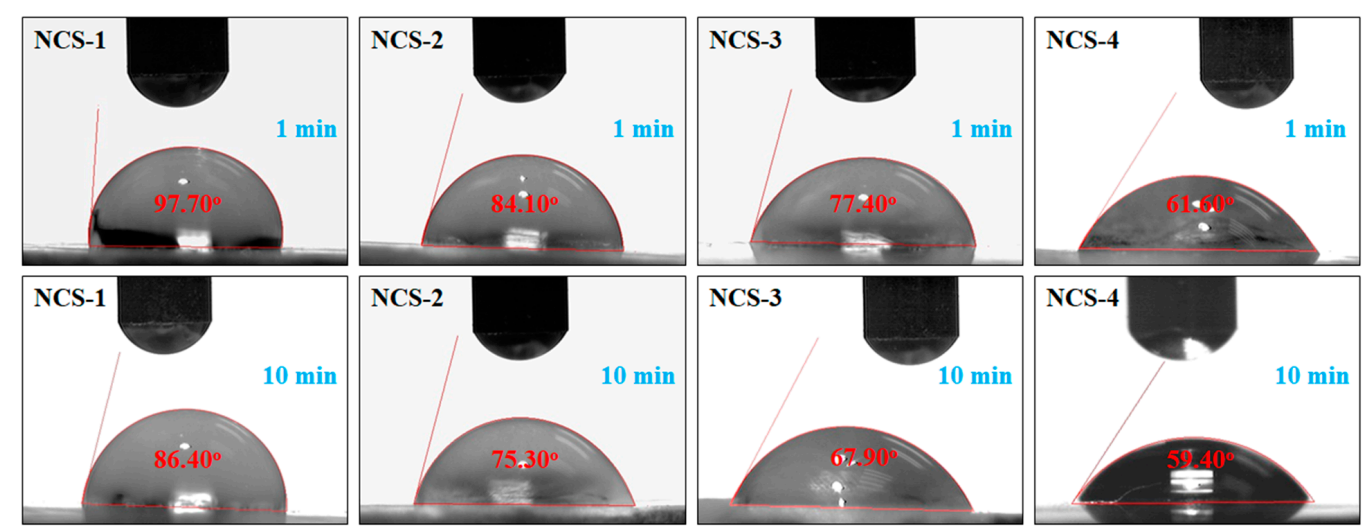

Figure 5. Wetting behavior of the nanocomposite scaffolds at different time intervals.

\subsection{Mechanical Testing}

The mechanical behavior of nanocomposite scaffolds was analyzed through the strain-stress curve (Figure 6A). The mechanical performance of the scaffold is an important character to support the fractured bone and helps the regeneration of defected bone by enhancing cellular physiology [37]. The mechanical strength of trabecular bone ranging from 1 to $10 \mathrm{MPa}$ as reported by different groups $[38,39]$. The mechanical strength of the composite scaffold should mimic the mechanical strength of the natural bone. A detailed mechanical behavior (compressive strength, strain \%, and Young's modulus) of all nanocomposite scaffolds have been summarized in the Table 1 . The increasing amount of reinforcement $(\mathrm{GO})$ into the polymeric composite increases the strength and modulus nanocomposite scaffolds. Therefore, all nanocomposite scaffolds began to be reinforced progressively as the amount of reinforcement agents increased, which could be attributed to the enhancement of stress transfer from NCS-1 scaffold to NCS-4 scaffold [40].

The value of Young's modulus is different for all scaffold samples due to the variable amount of GO. Collectively, the incorporation of GO on the mechanical properties of scaffolds imparted chemical interaction (as mentioned in Figure 2 (Left side)) that increased the mechanical strength of the nanocomposite scaffolds. It was worth noting, however, that HAp and GO were homogeneously mixed with a polymeric solution; this implies that HAp and GO were uniformly hybridized with the polymer phase at the molecular stage [41]. GO may also generate additional physical crosslinking due to possible $\mathrm{H}$-bonding among polymeric matrix and nHAp, and can serve as an efficient physical cross-linking agent. This might have contributed to microstructural improvements, and provided a close packaging to strengthen the nanocomposite scaffolds. Nonetheless, such nanocomposite scaffolds can be a potential biomaterial and might provide a similar mechanical strength as of human trabecular bone [38]. Henceforth, we could conclude that the mechanical properties of the porous composite scaffolds were optimal and can be applied in tissue engineering to treat bones with different mechanical strengths. 

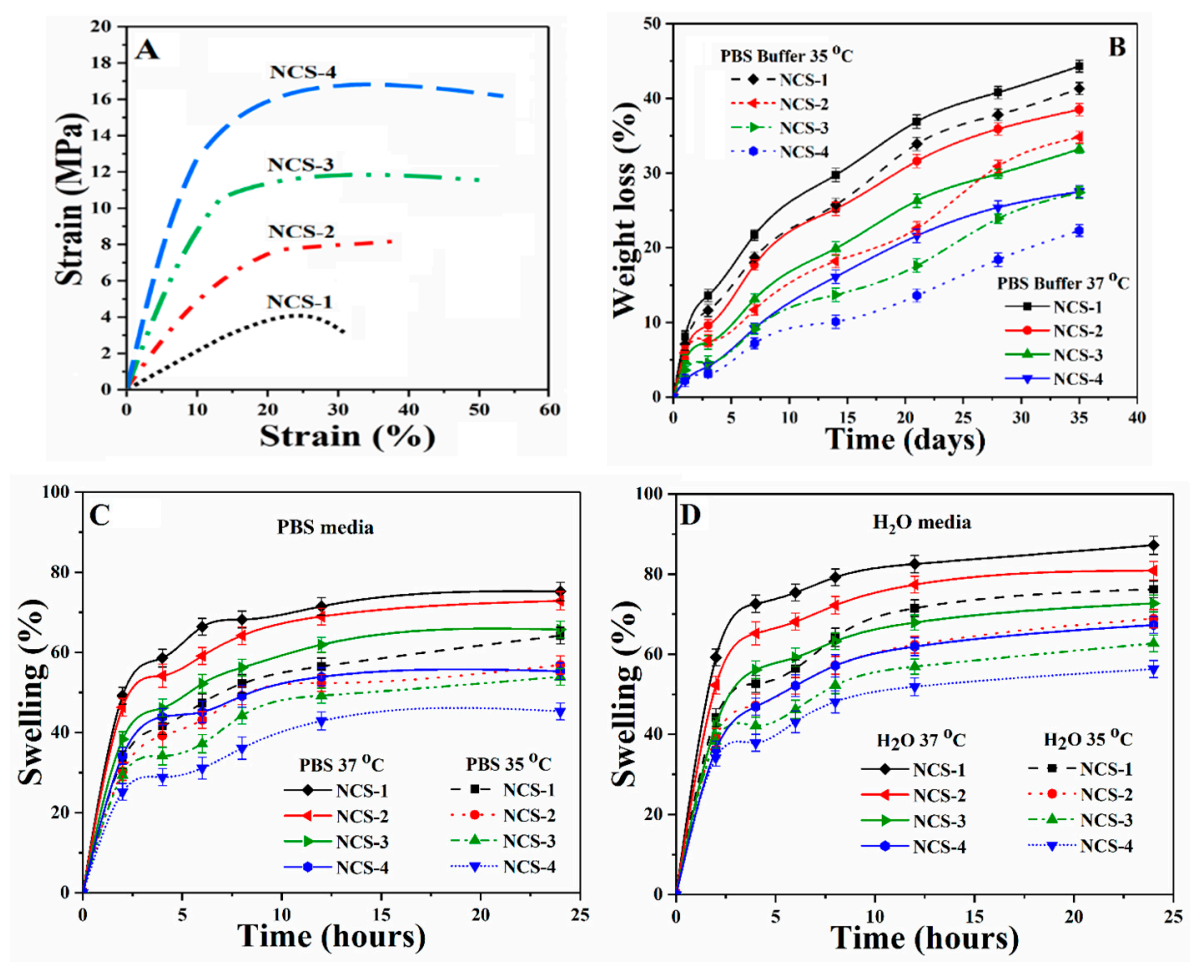

Figure 6. Presents (A) mechanical behavior of the nanocomposite scaffolds at room temperature, (B) the biodegradation under standard in-vitro conditions at different temperatures, and (C,D) the swelling of nanocomposite scaffolds at different temperatures and in different media.

\subsection{In-Vitro Biodegradation}

An ideal biomaterial for bone tissue corresponds to mechanical strength for host bone tissue with controllable degradation and resorption rate that creates space to facilitate bone growth [42]. The biodegradation of nanocomposite scaffolds was conducted under standard in-vitro condition using PBS solution for 35 days (Figure 6B). The nanocomposite scaffolds exhibited different degradation behavior due to different incorporated amounts of GO, and the mass loss profile was found to be linear as the time increases. The sample NCS-1 demonstrated maximum degradation at elevated temperature and NCS-4 presented the least degradation after 30 days. The degradation behavior of the nanocomposite scaffolds is dependent upon the hydrophobic behavior of polymeric matrix and crystallinity characteristics due to nHAp. The degradation of NCS-1 for 30 days was considerably greater than NCS-4, which confirms that the lower GO content leads to a faster scaffold degradation. Since GO has several oxygen-based functional groups that facilitated more H-bonding, and therefore the behavior of GO could be considered as a crosslinker. Therefore, we can conclude that GO content controlled the degradation of the scaffolds by improving matrix properties [43,44]. Biodegradation of polymeric-based scaffold or implants is an important issue in tissue engineering. The quick in-vivo degradation was reported due to the strong autocatalytic effect that produced acidic degradation products. These products are accumulated by the medium surrounding the implants. By changing frequent PBS media for in-vitro degradation can minimize the autocatalytic effect and the absence of certain enzymes helps to estimate in-vivo degradation behavior [45]. Monireh and colleagues have reported 10-12 weeks as the normal period for bone tissue integration [46]. The spinal fusion takes 9 months and cranio-maxillofacial takes 3-6 months as reported by Susmita and coworkers [1]. Therefore, the scaffolds with different degradation rates can be applied to different defective bone sites. Hereafter, we conclude that bone degradation can be controlled by regulating the amount of $\mathrm{GO}$, which corresponds to the rate of formation of new bone tissue. After implantation of a porous scaffold, scaffold material should support the host bone mechanically by retaining structural integrity on degradation into a complex in-vivo environment. 


\subsection{Swelling Analysis}

The swelling behavior of well-dried nanocomposite scaffolds was performed in phosphate-buffered saline (PBS) and aqueous media at room temperature (Figure 6C,D). An increase in fast swelling was found at the beginning of 5-7 h, then became stable as it attained an equilibrium state after $12 \mathrm{~h}$. It was observed that an increasing amount of GO caused the swelling due to its water-loving nature, which facilitated H-bonding with water molecules. Swelling is an important property of scaffolds that helps to regulate the exchange of gases and waste, and nutrients transported during metabolism [47]. The interconnected porosity and pore size increased, and surface area were observed to be increased during swelling, which facilitated cell adhesion, proliferation, and migration to form new tissues. The optimized swelling plays a vital role to enhance cell performance by controlled degradation of scaffolds, which are essential for bone regeneration [48]. Swelling phenomena is different at different temperatures ( 35 and $37^{\circ} \mathrm{C}$ ) and in different media (PBS solution and deionized water) due to the polymeric matrix. It was found that the maximum degree of hydration was found in water media at $37^{\circ} \mathrm{C}$ for NCS-4. Hence, an increasing amount of GO increases swelling at all temperatures and media [8]. Therefore, swelling of nanocomposite scaffolds confirmed the successful crosslinking and role of GO.

\subsection{Release of Silver Nanoparticles from Nanocomposite Scaffolds}

The release of silver sulfadiazine under in-vitro conditions has been presented in the PBS (Figure 6.). Silver-based nanocomposite scaffolds are significant in biomaterials, which release the silver over time to clear the microorganisms at the implant site. The sustained and prolonged release of silver is effective for antimicrobial activity [29]. The gradual release profile of silver from nanocomposite scaffolds fulfills the antimicrobial behavior of nanocomposite scaffolds (Figure 7). The amount of silver release was directly affected by the initial amount of silver doped inside the scaffolds. The linear release profile of silver-sulfadiazine was observed as $\sim 38.8 \%$ after $60 \mathrm{~min}$ and $\sim 90.6 \%$ after $260 \mathrm{~min}$, and then the release of silver-sulfadiazine was reduced, whereas the release of silver-sulfadiazine from NCS-1 was observed to be $\sim 11.3 \%$ after $60 \mathrm{~min}$ and $\sim 47.5 \%$ after $260 \mathrm{~min}$, and later it became continuous. It is also observed that the release of silver-sulfadiazine becomes reduce release to continuous release after $260 \mathrm{~min}$ from NCS-4 to NCS-1. The different silver-sulfadiazine release profile may be due to different physicochemical behavior of the nanocomposite scaffolds. Since the polymeric matrix of the nanocomposite scaffolds is similar to the extracellular matrix, and it interacted with the silver sulfadiazine drug through hydrogen-bonding or via weak van der Waals forces of attraction [49]. The quick-release of silver-sulfadiazine may be due to increased swelling. It was found that, initially, the release of silver is fast and later it became slow. The more release of silver ion facilitates in combating severe disease-causing pathogens at the initial stage after bone grafts.

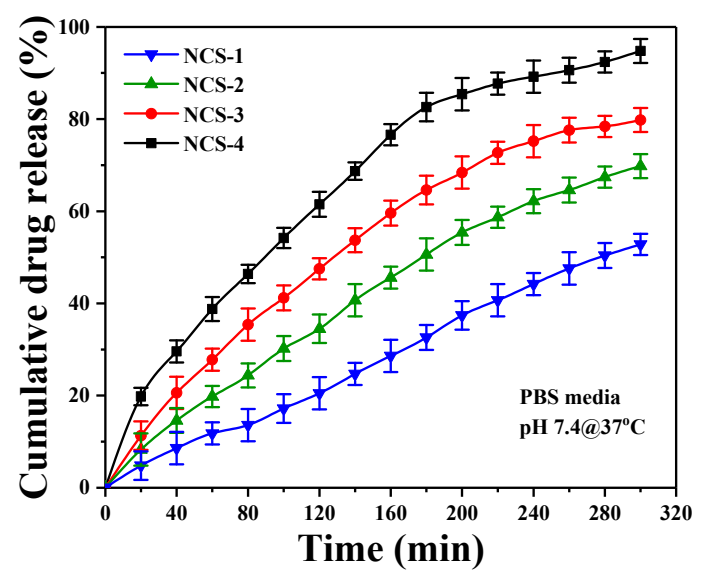

Figure 7. The drug release profile of the nanocomposite scaffold (NCS-4) under the controlled environment and physiological conditions. 


\subsection{In-Vitro Activities}

\subsubsection{Cell Viability and Optical Density}

In-vitro cell viability assay and optical density (Figure 8A,B) of nanocomposite scaffolds were studied against MC3T3-E1 cell lines. Different concentrations of nanocomposite scaffolds were prepared carefully $(0.500,1.000,1.500$, and $2.000 \mu \mathrm{m} / \mathrm{mL})$ and viability was recorded at different intervals $(24,48$, and $72 \mathrm{~h})$ after incubation under standard in-vitro conditions [50]. Maximum cell viability and cell proliferation were recorded at $2 \mu \mathrm{g} / \mathrm{mL}$ for NCS-4 as it contains more GO contents. GO imparts important physicochemical properties that facilitated cellular compatibility. However, increasing extract concentration $(2 \mu \mathrm{g} / \mathrm{mL})$ was found to be more favorable for cell viability and optical density. The developed nanocomposite scaffolds displayed their support for cell viability and increased cell proliferation without causing any toxicity towards pre-osteoblast cells (Figure 8).
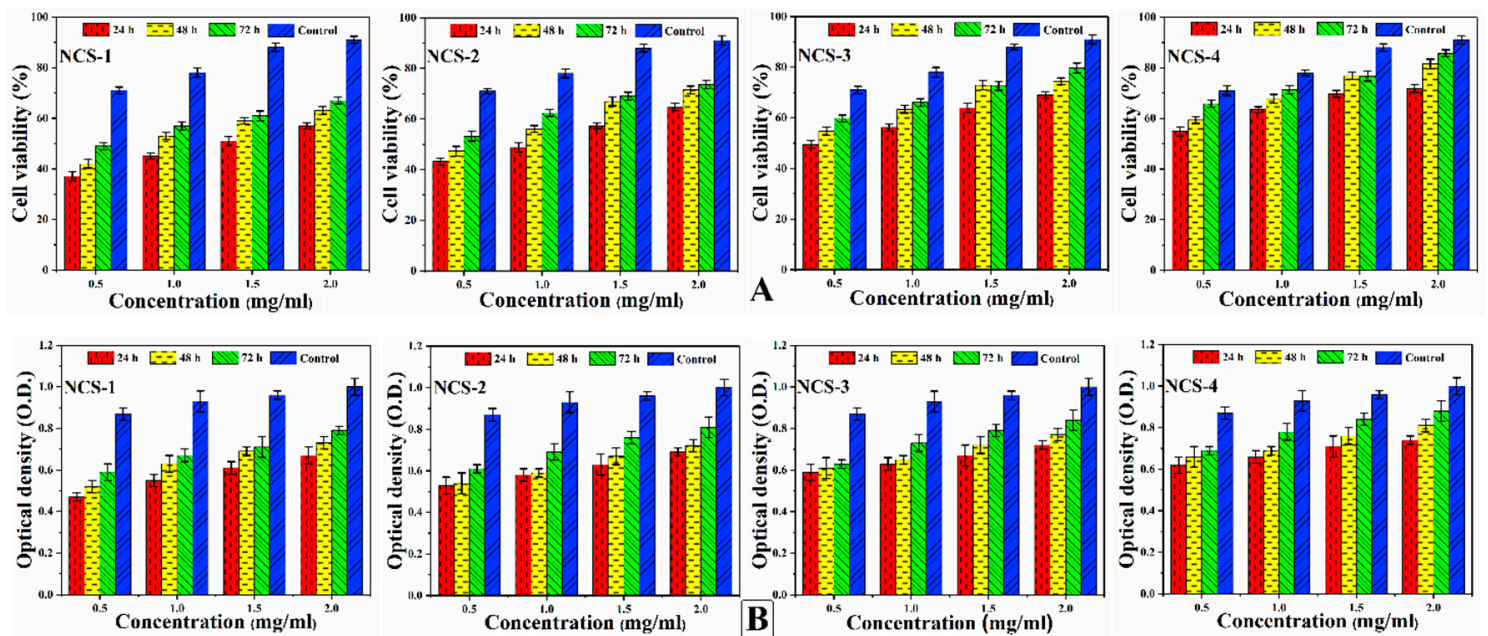

Figure 8. Presents the cellular behavior of MC3T3-E1 against different concentrations $(0.500,1.000$, 1.500 , and $2.000 \mu \mathrm{g} / \mathrm{mL}$ ) of nanocomposite scaffolds at different time intervals $(24,48$, and $72 \mathrm{~h})$ to

(A) determine cell viability (B) and optical density under standard in-vitro conditions.

\subsubsection{Cell Morphology}

The cellular morphology studies of MC3T3-E1 have been performed against nanocomposite scaffolds to determine their behavior towards cell growth and morphology (Figure 9). Different factors can influence cell differentiation by increasing biocompatibility over the surface of the substrate [51]. $\mathrm{GO}$ contains oxygen-based functional groups $\left(-\mathrm{COOH},-\mathrm{OSO}_{3},-\mathrm{H}\right.$, and $\left.-\mathrm{OH}\right)$ and these functional groups are essential for H-bonding. An increasing amount of $\mathrm{GO}$ enhances surface properties and functionalities that encourage cell adherence, differentiation, and growth [52,53]. The surface morphology of NCS-4 is much rougher, better interconnected, and more porous than all nanocomposite scaffolds. The NCS-4, therefore, demonstrated more and clearer cell spreading over time. The cell adhesion can be regulated by integrin binding over a modified surface [54]. Literature reports also support increasing functionalities modulate fibronectin adsorption and integrin-binding in the order, $\mathrm{OH}>\mathrm{COOH}>\mathrm{NH}_{2}>\mathrm{CH}_{3}$ [55]. The substantial change in absorbance was observed at different time intervals (24, 48, and $72 \mathrm{~h}$ ). NCS-3 and NCS-4 present excellent cylindrical cell morphology as compared to control due to hydrophilic nature. Hydrophilic behavior facilitates communication of substrate; hosts bone DNA that promotes cell adherence and proliferation to encourage bone regeneration. Moreover, after $48 \mathrm{~h}$, the cell spreading is quicker in cylindrical morphology, and, after $72 \mathrm{~h}$, no considerable difference was found among all samples especially NCS-3 and NCS-4. This was due to a high GO content that enhanced their physicochemical characteristics than in the rest of the samples. It can be explained by the hydrophilic surface characteristics, which is the necessary 
behavior of biomaterials in tissue integration. NCS-4 is more hydrophilic that supported cell adherence through H-bonding that facilitated cell proliferation (Figure 5). It may be possible that increasing incubation time may increase the cell proliferation to the grown new bone that can repair and regenerate the fractured bone [56,57].
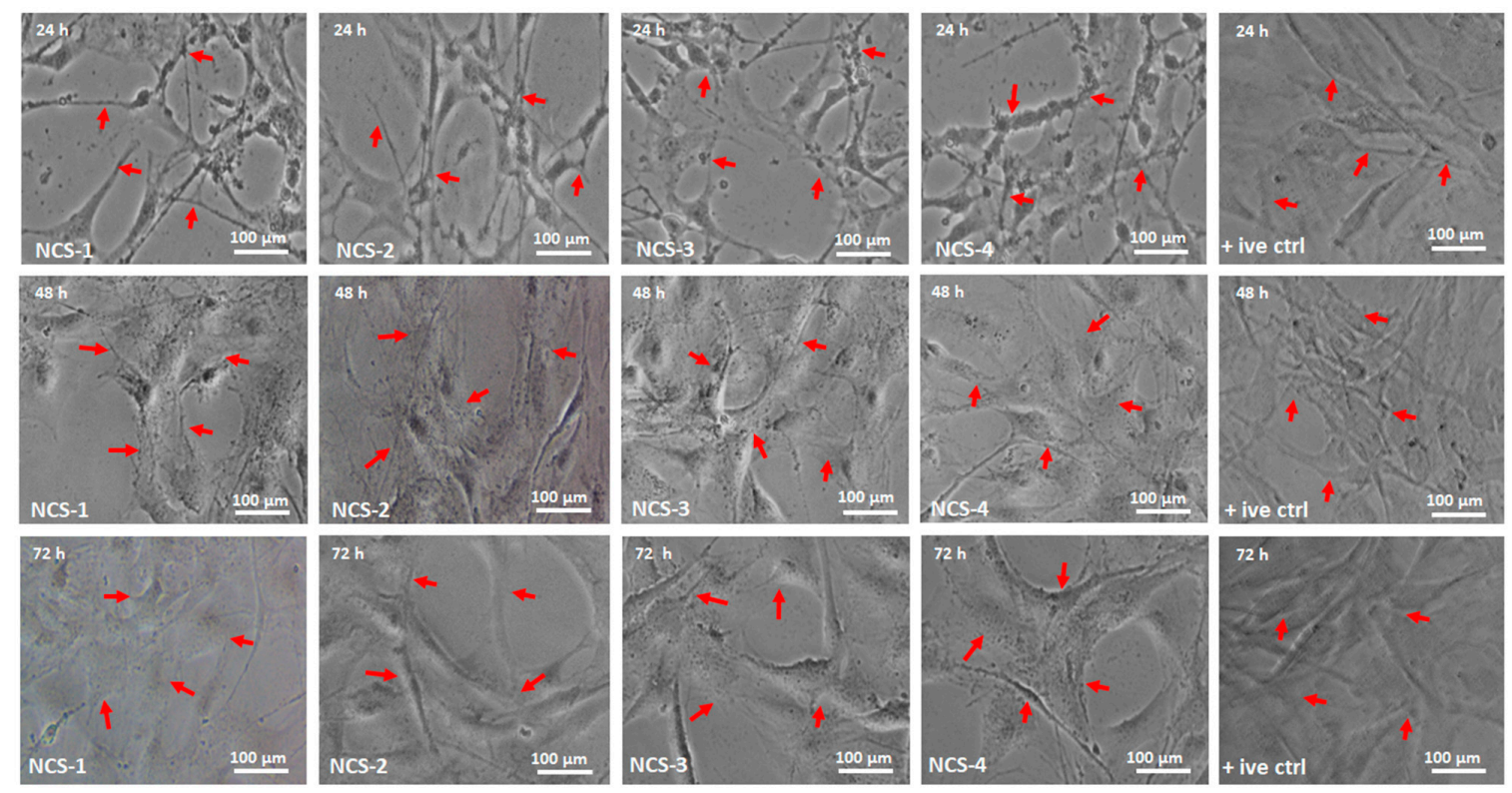

Figure 9. The cell morphology of MC3T3-E1 against all nanocomposite scaffolds and +ive control under different times $(24,48$, and $72 \mathrm{~h})$. The red arrows are presenting the proper adherence and cylindrical shapes of the cells in all scaffold samples (NCS-1, NCS-2, NCS-3, and NCS-4) under standard in-vitro conditions.

\subsubsection{SEM Analysis of Cell Culture and Attachment}

The Figure 10 presents the morphology of MC3T3-E1 cell adhered to the surface of all samples of nanocomposite scaffolds after $72 \mathrm{~h}$ of cell culture. It was found that cell adherence was increased as the amount of GO increased from NCS-1 to NCS-4. The culture cells spreading was found over the surface in cylindrical or polygonal form and also found in the pores of the scaffolds. Increasing cell culture time covered the surface and penetrated pores after culturing of $72 \mathrm{~h}$, as observed in all scaffolds (presented by red arrows). The increasing cell adherence can be explained by increasing hydrophilic character that facilitated adherence of cells over the surface through hydrogen bonding [58]. It also can be explained by rough morphology obtained due to porosity and owed to GO-sheets that have several oxygen-based functional groups, readily available for H-bonding [59]. Thus, increasing time may increase the gene expression for cell adherence and proliferation for reconstruction and growth of new bone tissue.
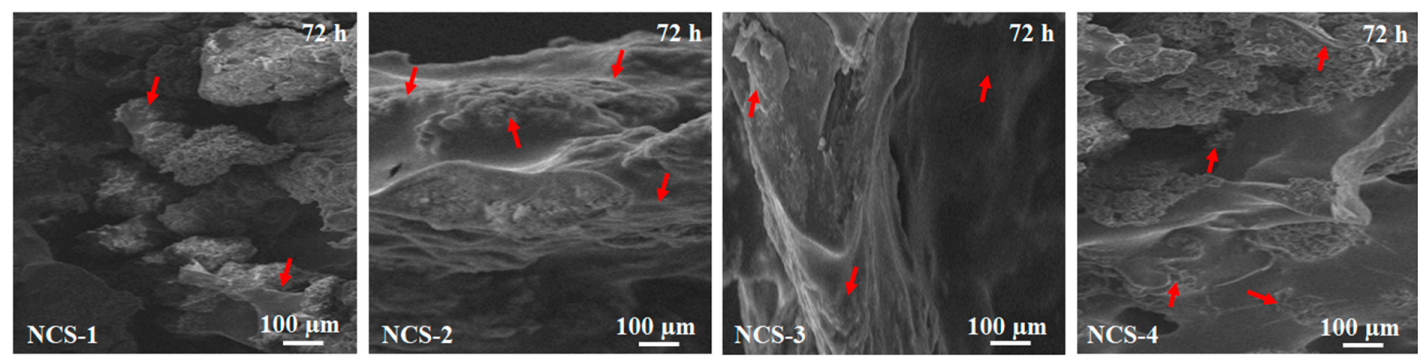

Figure 10. Presents the SEM analysis of cell culture and adherence for all nanocomposite scaffolds against MC3T3-E1 after $72 \mathrm{~h}$ and red arrows are indicating the culture and adherence of osteoblast cells. 


\section{Conclusions}

The novel porous foam-like nanocomposite scaffolds were fabricated through freeze drying from nanocomposite materials and coated with silver-sulphadiazine to deal with antibacterial activities. These nanocomposite materials revealed interesting bone-scaffold regeneration properties porous morphologies, hydrophilicity, and controlled biodegradation with worthy swelling behavior. The physicochemical properties of developed materials make them suitable to treat and repair fractured bone by enhanced osteo-regeneration and found to be biocompatible as depicted by in-vitro studies. The increasing amount of GO has improved physicochemical and biomechanical properties. The scaffolds sample NSC-4 with the maximum amount of GO exhibited a considerable cell adherence with cylinder interconnected cell morphology. The release of the antibacterial drug was found to be sustainable to address bacterial action after implantation. These nanocomposite scaffolds exhibit different mechanical properties that can be applied to repair fractured bone with different mechanical behavior. Hence, it can be concluded that these nanocomposite scaffolds (NSC-4) could serve as a potential biomaterial to repair fractured bone with load-bearing application in bone tissue engineering.

Author Contributions: Conceptualization, M.U.A.K. and S.I.A.R.; Data curation, M.U.A.K. and S.I.A.R.; Formal analysis, M.U.A.K. and S.I.A.R.; Funding acquisition, W.S.A.-A., S.N. and, S.I.A.R.; Investigation, M.U.A.K. and S.I.A.R. and M.R.A.K.; Methodology, M.U.A.K.; Project administration, M.U.A.K. and S.I.A.R.; Resources, S.I.A.R. and M.R.A.K.; Software, M.U.A.K.; Supervision, W.S.-A.A., M.R.A.K. and S.I.A.R.; Validation: M.U.A.K., S.I.A.R., and M.R.A.K.; Visualization, M.U.A.K. and M.R.A.K.; Writing—original draft, M.U.A.K.; Writing-review and editing, M.U.A.K., S.N. and S.I.A.R. All authors have read and agreed to the published version of the manuscript.

Funding: This research received no external funding.

Acknowledgments: The authors extend their appreciation to the Deputyship for Research and Innovation, Ministry of Education in Saudi Arabia, for funding this research work through the project number IFT20169.

Conflicts of Interest: The authors declare no conflict of interest.

\section{References}

1. Bose, S.; Roy, M.; Bandyopadhyay, A. Recent advances in bone tissue engineering scaffolds. Trends Biotechnol. 2012, 30, 546-554. [CrossRef] [PubMed]

2. De Witte, T.-M.; Fratila-Apachitei, L.E.; Zadpoor, A.A.; Peppas, N.A. Bone tissue engineering via growth factor delivery: From scaffolds to complex matrices. Regen. Biomater. 2018, 5, 197-211. [CrossRef] [PubMed]

3. Haj, J.; Haj Khalil, T.; Falah, M.; Zussman, E.; Srouji, S. An ECM-mimicking, mesenchymal stem cell-embedded hybrid scaffold for bone regeneration. BioMed. Res. Int. 2017, 2017, 1-12. [CrossRef] [PubMed]

4. Xu, Y.; Xia, D.; Han, J.; Yuan, S.; Lin, H.; Zhao, C. Design and fabrication of porous chitosan scaffolds with tunable structures and mechanical properties. Carbohydr. Polym. 2017, 177, 210-216. [CrossRef] [PubMed]

5. Sanz, M.; Dahlin, C.; Apatzidou, D.; Artzi, Z.; Bozic, D.; Calciolari, E.; De Bruyn, H.; Dommisch, H.; Donos, N.; Eickholz, P. Biomaterials and regenerative technologies used in bone regeneration in the craniomaxillofacial region: Consensus report of group 2 of the 15th European Workshop on Periodontology on Bone Regeneration. J. Clin. Periodontol. 2019, 46, 82-91. [CrossRef]

6. Aslam Khan, M.U.; Mehboob, H.; Abd Razak, S.I.; Yahya, M.Y.; Mohd Yusof, A.H.; Ramlee, M.H.; Sahaya Anand, T.J.; Hassan, R.; Aziz, A.; Amin, R. Development of polymeric nanocomposite (xyloglucan-co-methacrylic acid/hydroxyapatite/sio 2 ) scaffold for bone tissue engineering applications-in-vitro antibacterial, cytotoxicity and cell culture evaluation. Polymers 2020, 12, 1238. [CrossRef]

7. Khan, M.U.A.; Raza, M.A.; Mehboob, H.; Kadir, M.R.A.; Abd Razak, S.I.; Shah, S.A.; Iqbal, M.Z.; Amin, R. Development and in vitro evaluation of $\mathrm{K}$-carrageenan based polymeric hybrid nanocomposite scaffolds for bone tissue engineering. RSC Adv. 2020, 10, 40529-40542. [CrossRef]

8. Khan, M.U.A.; Haider, S.; Shah, S.A.; Abd Razak, S.I.; Hassan, S.A.; Kadir, M.R.A.; Haider, A. Arabinoxylan-co-AA/HAp/ $/ \mathrm{TiO}_{2}$ nanocomposite scaffold a potential material for bone tissue engineering: An in vitro study. Int. J. Biol. Macromol. 2020, 151, 584-594. [CrossRef] 
9. Samura, M.; Hosoyama, T.; Takeuchi, Y.; Ueno, K.; Morikage, N.; Hamano, K. Therapeutic strategies for cell-based neovascularization in critical limb ischemia. J. Transl. Med. 2017, 15, 49. [CrossRef]

10. Christy, P.N.; Basha, S.K.; Kumari, V.S.; Bashir, A.; Maaza, M.; Kaviyarasu, K.; Arasu, M.V.; Al-Dhabi, N.A.; Ignacimuthu, S. Biopolymeric nanocomposite scaffolds for bone tissue engineering applications-A review. J. Drug Deliv. Sci. Technol. 2020, 55, 101452. [CrossRef]

11. Shavandi, A.; Silva, T.H.; Bekhit, A.A.; Bekhit, A.E.-D.A. Keratin: Dissolution, extraction and biomedical application. Biomater. Sci. 2017, 5, 1699-1735. [CrossRef] [PubMed]

12. Aravamudhan, A.; Ramos, D.M.; Nada, A.A.; Kumbar, S.G. Natural polymers: Polysaccharides and their derivatives for biomedical applications. In Natural and Synthetic Biomedical Polymers; Elsevier: Amsterdam, The Netherlands, 2014; pp. 67-89.

13. Khan, M.U.A.; Raza, M.A.; Razak, S.I.A.; Abdul Kadir, M.R.; Haider, A.; Shah, S.A.; Mohd Yusof, A.H.; Haider, S.; Shakir, I.; Aftab, S. Novel functional antimicrobial and biocompatible arabinoxylan/guar gum hydrogel for skin wound dressing applications. J. Tissue Eng. Regen. Med. 2020, 14, 1488-1501. [CrossRef] [PubMed]

14. Noreen, A.; Akram, J.; Rasul, I.; Mansha, A.; Yaqoob, N.; Iqbal, R.; Tabasum, S.; Zuber, M.; Zia, K.M. Pectins functionalized biomaterials; a new viable approach for biomedical applications: A review. Int. J. Biol. Macromol. 2017, 101, 254-272. [CrossRef] [PubMed]

15. Ninan, N.; Muthiah, M.; Park, I.-K.; Elain, A.; Thomas, S.; Grohens, Y. Pectin/carboxymethyl cellulose/microfibrillated cellulose composite scaffolds for tissue engineering. Carbohydr. Polym. 2013, 98, 877-885. [CrossRef] [PubMed]

16. Wang, Q.; Gu, Z.; Jamal, S.; Detamore, M.S.; Berkland, C. Hybrid hydroxyapatite nanoparticle colloidal gels are injectable fillers for bone tissue engineering. Tissue Eng. Part A 2013, 19, 2586-2593. [CrossRef]

17. Qi, C.; Deng, Y.; Xu, L.; Yang, C.; Zhu, Y.; Wang, G.; Wang, Z.; Wang, L. A sericin/graphene oxide composite scaffold as a biomimetic extracellular matrix for structural and functional repair of calvarial bone. Theranostics 2020, 10, 741. [CrossRef]

18. Ma, R.; Wang, Y.; Qi, H.; Shi, C.; Wei, G.; Xiao, L.; Huang, Z.; Liu, S.; Yu, H.; Teng, C. Nanocomposite sponges of sodium alginate/graphene oxide/polyvinyl alcohol as potential wound dressing: In vitro and in vivo evaluation. Compos. Part B Eng. 2019, 167, 396-405. [CrossRef]

19. Escudero, M.; Llorente, I.; Pérez-Maceda, B.; San José-Pinilla, S.; Sánchez-López, L.; Lozano, R.; Aguado-Henche, S.; de Arriba, C.C.; Alobera-Gracia, M.; García-Alonso, M. Electrochemically reduced graphene oxide on $\mathrm{CoCr}$ biomedical alloy: Characterization, macrophage biocompatibility and hemocompatibility in rats with graphene and graphene oxide. Mater. Sci. Eng. C 2020, 109, 110522. [CrossRef]

20. Narayanan, K.B.; Kim, H.D.; Han, S.S. Biocompatibility and hemocompatibility of hydrothermally derived reduced graphene oxide using soluble starch as a reducing agent. Colloids Surf. B Biointerfaces 2020, 185, 110579. [CrossRef]

21. Saghir, S.; Iqbal, M.S.; Hussain, M.A.; Koschella, A.; Heinze, T. Structure characterization and carboxymethylation of arabinoxylan isolated from Ispaghula (Plantago ovata) seed husk. Carbohydr. Polym. 2008, 74, 309-317. [CrossRef]

22. Standard, A. D638: Standard Test Method for Tensile Properties of Plastics; ASTM International: West Conshohocken, PA, USA, 2010.

23. Repetto, G.; Del Peso, A.; Zurita, J.L. Neutral red uptake assay for the estimation of cell viability/cytotoxicity. Nat. Protoc. 2008, 3, 1125. [CrossRef] [PubMed]

24. Paluszkiewicz, C.; Stodolak, E.; Hasik, M.; Blazewicz, M. FT-IR study of montmorillonite-chitosan nanocomposite materials. Spectrochim. Acta Part A Mol. Biomol. Spectrosc. 2011, 79, 784-788. [CrossRef] [PubMed]

25. Hutchins, K.M. Functional materials based on molecules with hydrogen-bonding ability: Applications to drug co-crystals and polymer complexes. R. Soc. Open Sci. 2018, 5, 180564. [CrossRef] [PubMed]

26. Andiappan, M.; Sundaramoorthy, S.; Panda, N.; Meiyazhaban, G.; Winfred, S.B.; Venkataraman, G.; Krishna, P. Electrospun eri silk fibroin scaffold coated with hydroxyapatite for bone tissue engineering applications. Prog. Biomater. 2013, 2, 6. [CrossRef] [PubMed] 
27. Wang, J.; Wang, H.; Wang, Y.; Li, J.; Su, Z.; Wei, G. Alternate layer-by-layer assembly of graphene oxide nanosheets and fibrinogen nanofibers on a silicon substrate for a biomimetic three-dimensional hydroxyapatite scaffold. J. Mater. Chem. B 2014, 2, 7360-7368. [CrossRef] [PubMed]

28. Khan, M.U.A.; Al-Thebaiti, M.A.; Hashmi, M.U.; Aftab, S.; Abd Razak, S.I.; Abu Hassan, S.; Abdul Kadir, M.R.; Amin, R. Synthesis of silver-coated bioactive nanocomposite scaffolds based on grafted beta-glucan/hydroxyapatite via freeze-drying method: Anti-microbial and biocompatibility evaluation for bone tissue engineering. Materials 2020, 13, 971. [CrossRef]

29. Caló, E.; Khutoryanskiy, V.V. Biomedical applications of hydrogels: A review of patents and commercial products. Eur. Polym. J. 2015, 65, 252-267. [CrossRef]

30. Karahaliloglu, Z.; Kilicay, E.; Denkbas, E.B. Antibacterial chitosan/silk sericin 3D porous scaffolds as a wound dressing material. Artif. Cells Nanomed. Biotechnol. 2017, 45, 1172-1185. [CrossRef]

31. Riahi, N.; Liberelle, B.; Henry, O.; De Crescenzo, G. Impact of RGD amount in dextran-based hydrogels for cell delivery. Carbohydr. Polym. 2017, 161, 219-227. [CrossRef]

32. Murphy, C.M.; Haugh, M.G.; O'brien, F.J. The effect of mean pore size on cell attachment, proliferation and migration in collagen-glycosaminoglycan scaffolds for bone tissue engineering. Biomaterials 2010, 31, 461-466. [CrossRef]

33. Mandal, B.B.; Kundu, S.C. Cell proliferation and migration in silk fibroin 3D scaffolds. Biomaterials 2009, 30, 2956-2965. [CrossRef] [PubMed]

34. Lopez-Heredia, M.A.; Sohier, J.; Gaillard, C.; Quillard, S.; Dorget, M.; Layrolle, P. Rapid prototyped porous titanium coated with calcium phosphate as a scaffold for bone tissue engineering. Biomaterials 2008, 29, 2608-2615. [CrossRef] [PubMed]

35. Van Wachem, P.; Hogt, A.; Beugeling, T.; Feijen, J.; Bantjes, A.; Detmers, J.; Van Aken, W. Adhesion of cultured human endothelial cells onto methacrylate polymers with varying surface wettability and charge. Biomaterials 1987, 8, 323-328. [CrossRef]

36. Bauer, S.; Park, J.; von der Mark, K.; Schmuki, P. Improved attachment of mesenchymal stem cells on super-hydrophobic $\mathrm{TiO}_{2}$ nanotubes. Acta Biomater. 2008, 4, 1576-1582. [CrossRef] [PubMed]

37. Neira, I.S.; Kolen'ko, Y.V.; Kommareddy, K.P.; Manjubala, I.; Yoshimura, M.; Guitián, F. Reinforcing of a calcium phosphate cement with hydroxyapatite crystals of various morphologies. ACS Appl. Mater. Interfaces 2010, 2, 3276-3284. [CrossRef]

38. Kim, D.K.; Kim, J.I.; Hwang, T.I.; Sim, B.R.; Khang, G. Bioengineered osteoinductive broussonetia Kazinoki/silk fibroin composite scaffolds for bone tissue regeneration. ACS Appl. Mater. Interfaces 2017, 9, 1384-1394. [CrossRef] [PubMed]

39. Wang, S.; Yang, Y.; Zhao, Z.; Wang, X.; Mikos, A.G.; Qiu, Z.; Song, T.; Sun, X.; Zhao, L.; Zhang, C. Mineralized collagen-based composite bone materials for cranial bone regeneration in developing sheep. ACS Biomater. Sci. Eng. 2017, 3, 1092-1099. [CrossRef]

40. Tserki, V.; Matzinos, P.; Kokkou, S.; Panayiotou, C. Novel biodegradable composites based on treated lignocellulosic waste flour as filler. Part I. Surface chemical modification and characterization of waste flour. Compos. Part A Appl. Sci. Manuf. 2005, 36, 965-974. [CrossRef]

41. Lei, B.; Shin, K.-H.; Noh, D.-Y.; Jo, I.-H.; Koh, Y.-H.; Choi, W.-Y.; Kim, H.-E. Nanofibrous gelatin-silica hybrid scaffolds mimicking the native extracellular matrix (ECM) using thermally induced phase separation. J. Mater. Chem. 2012, 22, 14133-14140. [CrossRef]

42. Porter, J.R.; Ruckh, T.T.; Popat, K.C. Bone tissue engineering: A review in bone biomimetics and drug delivery strategies. Biotechnol. Prog. 2009, 25, 1539-1560. [CrossRef]

43. Sivashankari, P.; Moorthi, A.; Abudhahir, K.M.; Prabaharan, M. Preparation and characterization of three-dimensional scaffolds based on hydroxypropyl chitosan-graft-graphene oxide. Int. J. Biol. Macromol. 2018, 110, 522-530. [CrossRef] [PubMed]

44. Shuai, C.; Li, Y.; Yang, W.; Yu, L.; Yang, Y.; Peng, S.; Feng, P. Graphene oxide induces ester bonds hydrolysis of poly-L-lactic acid scaffold to accelerate degradation. Int. J. Bioprinting 2020, 6, 249. [CrossRef]

45. Agrawal, C.; McKinney, J.; Lanctot, D.; Athanasiou, K. Effects of fluid flow on the in vitro degradation kinetics of biodegradable scaffolds for tissue engineering. Biomaterials 2000, 21, 2443-2452. [CrossRef]

46. Kouhi, M.; Prabhakaran, M.P.; Shamanian, M.; Fathi, M.; Morshed, M.; Ramakrishna, S. Electrospun PHBV nanofibers containing HA and bredigite nanoparticles: Fabrication, characterization and evaluation of mechanical properties and bioactivity. Compos. Sci. Technol. 2015, 121, 115-122. [CrossRef] 
47. Hoo, S.P.; Loh, Q.L.; Yue, Z.; Fu, J.; Tan, T.T.; Choong, C.; Chan, P.P. Preparation of a soft and interconnected macroporous hydroxypropyl cellulose methacrylate scaffold for adipose tissue engineering. J. Mater. Chem. B 2013, 1, 3107-3117. [CrossRef]

48. Wu, S.; Duan, B.; Lu, A.; Wang, Y.; Ye, Q.; Zhang, L. Biocompatible chitin/carbon nanotubes composite hydrogels as neuronal growth substrates. Carbohydr. Polym. 2017, 174, 830-840. [CrossRef]

49. Bibby, D.C.; Davies, N.M.; Tucker, I.G. Mechanisms by which cyclodextrins modify drug release from polymeric drug delivery systems. Int. J. Pharm. 2000, 197, 1-11. [CrossRef]

50. Allen, R.J.; Waclaw, B. Bacterial growth: A statistical physicist's guide. Rep. Prog. Phys. 2018, 82, 016601. [CrossRef]

51. Bet, M.; Goissis, G.; Vargas, S.; Selistre-de-Araujo, H. Cell adhesion and cytotoxicity studies over polyanionic collagen surfaces with variable negative charge and wettability. Biomaterials 2003, 24, 131-137. [CrossRef]

52. Dadsetan, M.; Pumberger, M.; Casper, M.E.; Shogren, K.; Giuliani, M.; Ruesink, T.; Hefferan, T.E.; Currier, B.L.; Yaszemski, M.J. The effects of fixed electrical charge on chondrocyte behavior. Acta Biomater. 2011, 7, 2080-2090. [CrossRef]

53. Makohliso, S.A.; Valentini, R.F.; Aebischer, P. Magnitude and polarity of a fluoroethylene propylene electret substrate charge influences neurite outgrowth in vitro. J. Biomed. Mater. Res. 1993, 27, 1075-1085. [CrossRef] [PubMed]

54. Tang, L.; Thevenot, P.; Hu, W. Surface chemistry influences implant biocompatibility. Curr. Top. Med. Chem. 2008, 8, 270-280. [CrossRef] [PubMed]

55. Keselowsky, B.G.; Collard, D.M.; García, A.J. Integrin binding specificity regulates biomaterial surface chemistry effects on cell differentiation. Proc. Natl. Acad. Sci. USA 2005, 102, 5953-5957. [CrossRef] [PubMed]

56. Teymouri, S.; Calejo, M.T.; Hiltunen, M.; Sorkio, A.; Juuti-Uusitalo, K.; Skottman, H.; Kellomäki, M. Collagen-immobilized polyimide membranes for retinal pigment epithelial cell adherence and proliferation. Cogent Chem. 2017, 3, 1292593. [CrossRef]

57. Fan, Y.; Cui, F.; Chen, L.; Zhai, Y.; Xu, Q. Improvement of neural cell adherence to silicon surface by hydroxyl ion implantation. Surf. Coat. Technol. 2000, 131, 355-359. [CrossRef]

58. Lumetti, S.; Manfredi, E.; Ferraris, S.; Spriano, S.; Passeri, G.; Ghiacci, G.; Macaluso, G.; Galli, C. The response of osteoblastic MC3T3-E1 cells to micro-and nano-textured, hydrophilic and bioactive titanium surfaces. J. Mater. Sci. Mater. Med. 2016, 27, 68. [CrossRef]

59. Wang, P.; Yu, T.; Lv, Q.; Li, S.; Ma, X.; Yang, G.; Xu, D.; Liu, X.; Wang, G.; Chen, Z. Fabrication of hydroxyapatite/hydrophilic graphene composites and their modulation to cell behavior toward bone reconstruction engineering. Colloids Surf. B Biointerfaces 2019, 173, 512-520. [CrossRef]

Publisher's Note: MDPI stays neutral with regard to jurisdictional claims in published maps and institutional affiliations.

(C) 2020 by the authors. Licensee MDPI, Basel, Switzerland. This article is an open access article distributed under the terms and conditions of the Creative Commons Attribution (CC BY) license (http://creativecommons.org/licenses/by/4.0/). 